\title{
Economic Impact of COVID-19 on the European Tourism Sector with Special View on Croatian Tourism
}

\author{
Dragan Kovačević \\ Management Board, JANAF Plc., Zagreb, Croatia \\ Email:dragan.kovacevic@janaf.hr
}

How to cite this paper: Kovačević, D. (2020). Economic Impact of COVID-19 on the European Tourism Sector with Special View on Croatian Tourism. Modern Economy, 11, 1652-1670.

https://doi.org/10.4236/me.2020.1110115

Received: July 31,2020

Accepted: October 27, 2020

Published: October 30, 2020

Copyright $\odot 2020$ by author(s) and Scientific Research Publishing Inc. This work is licensed under the Creative Commons Attribution International License (CC BY 4.0).

http://creativecommons.org/licenses/by/4.0/

\section{(c) (i) Open Access}

\begin{abstract}
From the mid-twentieth century, the share of service sector increased from $60 \%$ to $80 \%$ and amongst service, tourism is fast-growing industry. Globally, tourism is an important component of the service economy, representing one-third of international trade in services. This sector is the import engine of economic growth in many charts as globally, and it is a very dynamic and growing sector in the last decades. Europe is the world's most visited destination with more than 700 million arrivals, representing $51 \%$ of the all arrivals. Amongst EU Members, the most attractive destinations are France, Spain, Italy, Germany, Greece; but nevertheless, Croatia recorded a remarkable increase in tourist arrivals. Tourism sector has experienced a major growth in recent years. However, this sector is very vulnerable because tourist products represent luxury goods depending on many economic and social factors. Besides the fact mentioned above, the latest trends about coronavirus will set out many tourism companies in an unenviable situation, dropping revenues among the lowest level in history. In this paper, author estimate potential losses in European tourism sector under circumstances of closed borders. In addition, less pessimistic scenario has been forecasted, achieving the level of $30 \%$ of the previous year.
\end{abstract}

\section{Keywords}

Tourism, Croatia, COVID-19, Europe

\section{Introduction}

From the mid-twentieth century, the share of service sector of GDP has been expanded and by emphasizing the importance of services and among them, tour- 
ism has taken a very high position. The direct contribution of the travel and tourism industry accounted for 3.3 percent of the total global GDP in 2019 (Ilo.org, 2011). Comparatively, the total contribution of the travel and tourism industry in 2019 accounted for 10.4 percent of the total GDP worldwide (Statista.com, 2020). Tourism is a very significant sector of some national economy, with its share in the GDP ranging from $5 \%$ to over $20 \%$. It is also a sector with rising economic impact on the global economy with 330 million people employed in tourism presently while ten years ago it was only 235 million jobs.

Tourism industry has become a remarkable stimulating factor in many countries, as well as globally. According to the latest data from the World Tourism Organization (WTO), globally, the arrival of international tourists has increased from 527 million in 1995, to 1.5 billion in 2019.

In the last few decades, tourism has noticed rising growth rates generating increased income, improving balance of payments, creating jobs, developing many local communities and the whole countries. In some countries and regions, tourism represents more than $10 \%$ of the GDP while some less developed countries depend completely on tourism, like Maldives (38.9\%), British virgin Islands (32.96\%), Macao (28.05\%), etc. (2018) (World Bank, 2020). Tourism has a very high multiplicative effect on the entire economy, but it is also a very vulnerable sector. Many exogenous factors can cause undetected damage on tour, such as war, terrorism, financial crisis or even current virus. During the recession in 2008 (Lee, 2008), tourism sector showed significant drop in arrivals $(-4 \%)$, revenues and profits. After economic crisis, tourism has been accomplishing ten very successful years with an average growth rate of $5.1 \%$ and the most successful year, 2017, enjoyed rising rate of 7.2\%. After the peak mentioned above, tourism arrivals achieved decreasing trends in 2020 but with trends of recovery (https://www.e-unwto.org/, download, 29.4.2020).

In 2019, all destinations worldwide registered around 1.5 billion international tourist arrivals and from that number, 50.8\% arrivals were reported in Europe, 25\% in Asia and Pacific, 15\% in America and 5\% in Africa. All regions registered the increasing number of tourists whereas Middle East, Asia and Pacific enjoyed an above average growth. Meanwhile, Europe and Africa were in line with the world average (World Tourism Barometer, 2020). Tourism is growing rapidly in Asian countries because their government supports it through various programs and subsidies.

In the period from 2014 to 2018, the number of international visitors increased for $5.4 \%$ in the EU-28, 5.3\% in OECD countries and 5.5\% in the world. During the above-mentioned period, some countries have shown a rapid growth of more than $10 \%$ like Iceland $(23.8 \%)$ or Japan $(23.5 \%)$ and around 10 percent, like Portugal (11.9\%), Slovakia (11.2), Chile (10.7\%) and Hungary (10.1\%). (OECD, 2020) in spite of this double digit growth rates, five destinations were receiving one third of all inbound arrivals and these are France, Spain, Chine, the United States and Italy. 
In 2018, only several countries achieved a deficit in balance of payment in the travelling segment: Germany, Belgium, the Netherlands, Sweden, Finland, Romania, Denmark and Ireland. For all EU Members, tourism is a significant source of export's revenues.

Some countries depend strongly on tourism revenues, while others realized not as much as positive or balanced amount of tourism receipts and expenditures. Coronavirus and strong emphasis on the health care emerging in the world in 2020 took a toll on inbound tourism in the whole region. Many countries took the lock-down strategy at the beginning of crisis with a strong impact of their government's revenues, while it has the most powerful effect for the tourism-dependent states. From the beginning of June, according to forecasting, all business activities will run again but tourism and travelling will face with deep decline due to the fact that many countries will not open their borders or have some restrictions.

Analyzing the trends and development of tourism in Croatia, we note that the number of nights of foreign tourists, which make up $92.26 \%$ of the total number of tourism nights in 2019, in the 2010-2019 period, Croatia achieved, after Lithuania (10.92\%), the highest average annual growth among the EU members of $10.65 \%$ compared to $4.09 \%$ in the total EU27. The number of nights spent at tourist accommodation establishments reached 84.1 million with a share in the EU27 of $6.29 \%$, i.e. is higher by $74.3 \%$ than in 2010 (Eurostat, 2020a, 2020b). However, other economic activities did not follow such accelerated growth, so today Croatia has a relatively high dependence on tourism trends with a share of $10.9 \%$ in total gross value added compared to $6.7 \%$ in Portugal, 3.1\% in Austria, $2 \%$ in Poland, etc. The health and economic crisis in 2020 causes a significant decline in economic and especially tourist activities, but also indicates opportunities related to the growth potential of domestic tourists, as well as the need to develop other promising activities.

This paper is divided into 5 parts. Besides the introduction and the conclusion, the tourism sector in the world as well as in the EU is analyzed, together with its trends and performances in the last decade and with special view on Croatia. In the third section, the direct and indirect effects of tourism sector on national economy followed by calculating the direct loss of the coronavirus on European economies is reviewed. Additionally, we analyze correlation between tourist activities (nights spent at tourist accommodation establishments) and some macroeconomic indicators (GDP growth rate, tax revenues) as well as challenges regarding implication of Covid-19 on tourism.

\section{Tourism Sector in the EU with Special View on Croatia}

The European Union (EU) is an economic and political union, comprising of 27 member countries and around 430 million people, setting out the free movement of people, goods, services, and capitals inside the single market. Amongst Member States, 19 out of 27 share the same currency-the euro. 
With all these facts, EU Member States represent strong potential in terms of tourism demand, but with rich cultural heritage and historical monuments, luxury accommodation units, and good climate conditions, countries are also very competitive partners on the supply side.

Tourism sector, both globally and in the EU, has rapidly increased in the last ten years. After the global economic crisis in 2008, employment in all sectors grew averagely in the world by $11 \%$ while growth in tourism was $35 \%$. In 2017 , one in ten enterprises of non-financial business economy in the EU belonged to the tourism industry. Forthcoming, in 2017 the total number of enterprises in non-financial sector in EU 27 was 22.3 million while 2.3 million belonged to tourism industry. According to regional approach, more than 50\% of EU-27 tourism industry was concentrated in the four biggest countries; Italy, France, Spain and Germany. Croatian enterprises participated with only $1 \%$ in the total number of firms in European tourism sector. Mentioned sector in 2017 employed around 12 million persons, divided on, 58.5\% to food and beverage serving and $19.8 \%$ to accommodation (www.eurostat.eu). In Croatian accommodation business, $1.55 \%$ European workers were employed, while this percentage was around $1 \%$ in food and beverage sector.

Europe is the largest region in terms of international travel recipes, with $€ 406$ billion earned in 2016 or $37 \%$ of the world's receipts at destinations (Pololikashvili, 2018).

Tourism activity measured by the number of total nights spent in the EU27 increased from 2010 to 2019 by $31.4 \%$ and in 2019 this number has reached 2.844 billion, of which the number of nights spent by foreign tourists is $47.7 \%$. Tourism in EU27 is highly concentrated to four countries. In 2019 more than $62.95 \%$ of all nights spent at tourist accommodation establishments in EU were concentrated in Spain (16.52\%), France (15.70\%), Germany (15.37\%), Italy 15.36\%, etc. (Figure 1).

Only Czechia, Germany, Greece, Croatia, Hungary, Netherlands, Poland and Portugal recorded an all-time increasing growth rate of nights spent. During the last decade, the number of nights spent in tourist accommodation establishments in all EU Member States has generally shown an upward trend, especially after the recovery from the financial and economic crises.

The tourism potential of the Republic of Croatia, according to the total number of nights spent by tourists, was $3.21 \%$ of the total number of nights spent by tourists in the EU27 (2019), with a trend of growth. The number of nights spent by tourists in Croatia was 91.178 million, compared to 2.844 billion in EU27.

However, Croatia has significantly more potential in relation to the share of nights spent by foreign tourists in the EU27, which is $6.29 \%$ in 2019 (7th in a row), compared to $3.61 \%$ in 2010 with a significant growth trend from 2010 to 2017, and after that, only a slight growth (Figure 2). Number of nights spent by foreign tourists in Croatia in 2019 was 84.124 million, compared to 1.337 billion in the EU-27 (Figure 3). 


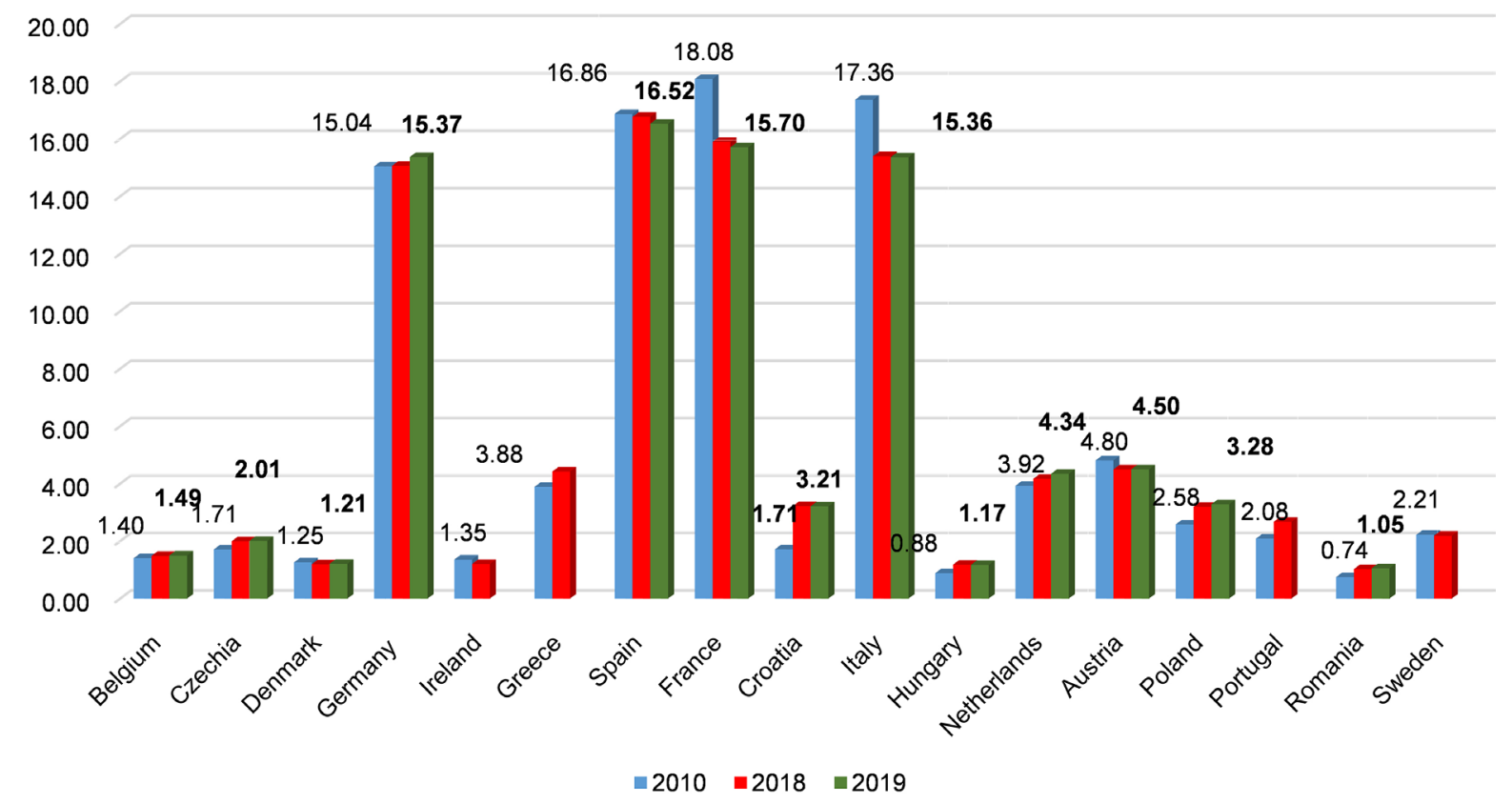

Figure 1. Share of the total number of nights spent by tourists from the largest tourist EU Member States (\%). Source: based on data from https://ec.europa.eu/eurostat/data/database, Table. Hotels; holiday and other short-stay accommodation; camping grounds, recreational vehicle parks and trailer parks, Total. Notes: The EU27 includes Member States from January 2020. The Figure comprises the members with a share greater than $1 \%$ in the total EU27. The data for 2017-2019 for some countries are not available.

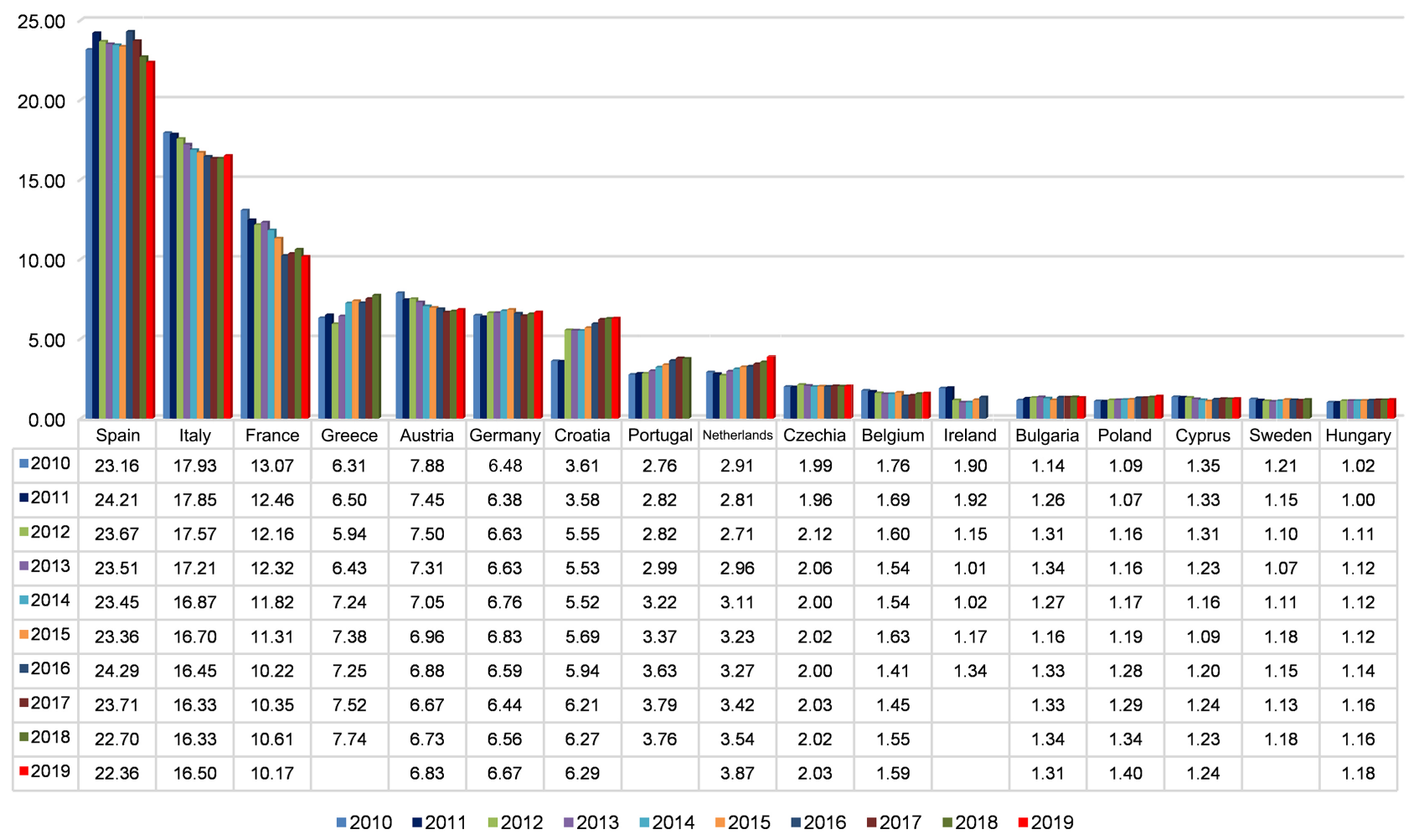

Figure 2. Share of nights spent by foreign tourists from Member States in total EU27 (\%). Source: based on data from https://ec.europa.eu/eurostat/data/database, Table. Hotels; holiday and other short-stay accommodation; camping grounds, recreational vehicle parks and trailer parks, foreign country. Note: The Figure comprises the members with a share greater than $1 \%$ in the total EU27. 


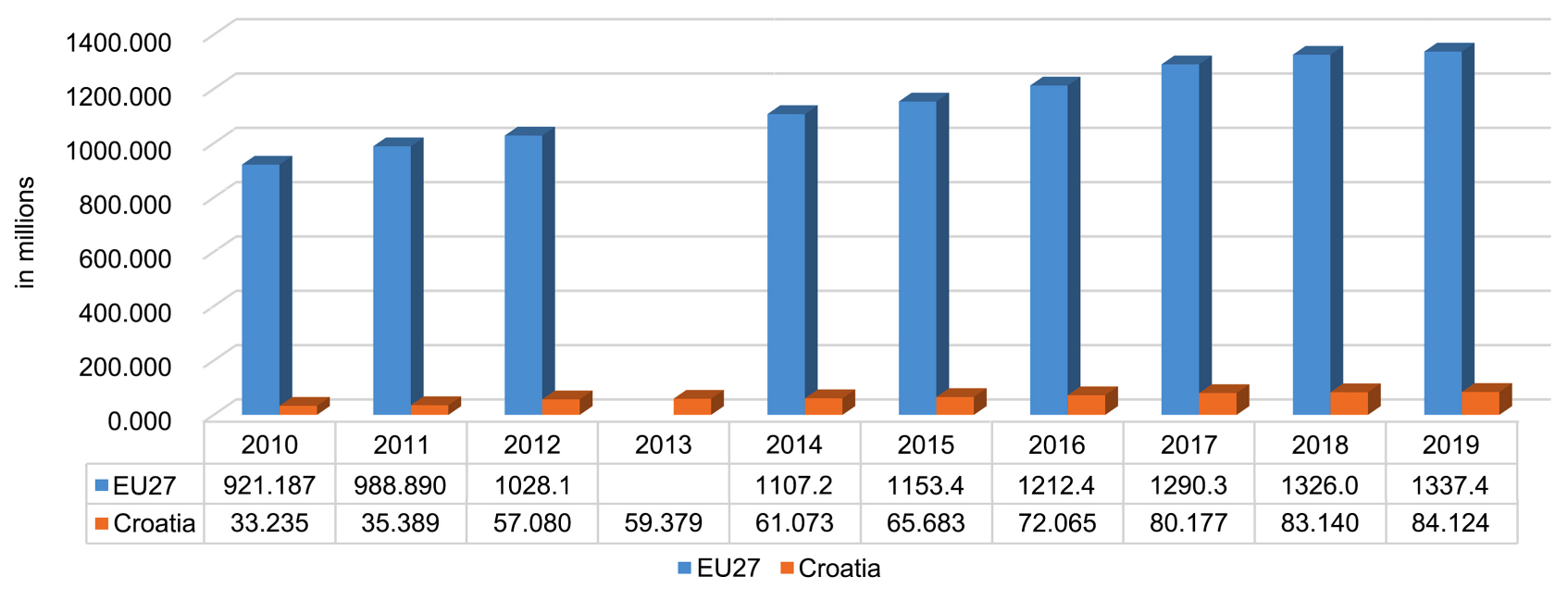

Figure 3. Number of nights spent by foreign tourists in EU27 and Croatia. Source: based on data from

https://ec.europa.eu/eurostat/data/database, Table. Hotels; holiday and other short-stay accommodation; camping grounds, recreational vehicle parks and trailer parks, foreign country. Note: The data in 2013 of EU27 are not available.

In 2019 Spain has the largest share of $22.36 \%$, followed by Italy $16.50 \%$ with a decreasing trend, France $10.17 \%$ with a decreasing trend, Greece $7.74 \%$ (2018), Austria 6.83\%, Germany 6.67\%, etc. (Figure 2).

Croatia is very sensitive to the changes in number of nights spent by foreign tourists, whose share is $92.26 \%$ in the total number of tourist nights. Only Malta has such a high share of $95.21 \%$, followed by Cyprus with $94.24 \%$, then slightly less Austria 71.46\%, Latvia 69.9\%, Bulgaria 64.37\%, Spain 63.66\%, etc. The share in whole EU27 is $47.47 \%$ (Table 1).

Such a high share of foreign tourists in the total number of nights spent by tourists demonstrates high dependence on foreign tourist arrivals, but also the potential provided by domestic tourists and the role of marketing, which should be intensified in order to significantly increase their number.

Number of nights spent by domestic tourists in Croatia in 2019 was only 4.4 million, compared to 603.1 million in the EU27, i.e. $0.71 \%$ in the total EU27, with a growth trend from 2010 to 2012 and then very mild growth until 2019. Croatia has only $7.7 \%$ of nights spent by domestic tourists in the total number of nights spent by tourists, compared to 53\% in the EU27 (Figure 4).

Romania has the largest share of domestic tourists in the total number of tourism nights among EU27 members, 82.4\%, followed by Poland, 80.0, Germany 79.6, etc., and another 11 countries have a share of about $50 \%$ and more.

At the same time, the largest number of nights spent by domestic tourists in the total number of EU27 has France $27.92 \%$, followed by Germany $18.85 \%$, Italy $12.55 \%$, Spain $8.48 \%$, the Netherlands 7.86\%, Poland 5.97\%. etc., however 21 countries have a share of around or below $2 \%$ (Figure 5).

One indicator of the tourism industry's sensitivity is its seasonality.

If we analyze monthly data of night spent at tourist accommodation establishment in 2019, the highest seasonality is observed in Croatia, Greece and Bulgaria, as well as in Italy, Cyprus, Denmark and France (Table 2). 
Table 1. Share of nights spent by foreign tourists in the total number of nights of Member States (\%).

\begin{tabular}{|c|c|c|c|}
\hline & 2010 & 2018 & 2019 \\
\hline EU27 & 41.19 & 47.99 & 47.47 \\
\hline Belgium & 53.37 & 49.77 & 49.88 \\
\hline Bulgaria & 65.35 & 66.12 & 64.37 \\
\hline Czech Republic & 49.76 & 48.2 & 47.66 \\
\hline Denmark & 33.09 & 37.84 & 37.8 \\
\hline Germany & 18.33 & 20.73 & 20.43 \\
\hline Estonia & 68.15 & 62.96 & \\
\hline Ireland & 59.75 & & \\
\hline Greece & 69.19 & 83.33 & \\
\hline Spain & 58.47 & 64.47 & 63.66 \\
\hline France & 30.77 & 31.78 & 30.45 \\
\hline Croatia & 89.8 & 92.82 & 92.26 \\
\hline Italy & 43.99 & 50.49 & 50.53 \\
\hline Cyprus & 90.2 & 94.66 & 94.24 \\
\hline Latvia & 67.48 & 69.72 & 69.90 \\
\hline Lithuania & 56.28 & 46.18 & 46.30 \\
\hline Luxembourg & 92.34 & 88.16 & \\
\hline Hungary & 49.18 & 46.73 & 47.45 \\
\hline Malta & 95.34 & 95.76 & 95.21 \\
\hline Netherlands & 31.58 & 40.49 & 41.92 \\
\hline Austria & 69.83 & 71.3 & 71.46 \\
\hline Poland & 18.04 & 19.97 & 20.02 \\
\hline Portugal & 56.37 & 67.00 & \\
\hline Romania & 17.24 & 18.64 & 17.63 \\
\hline Slovenia & 55.56 & & \\
\hline Slovakia & 36.62 & 36.6 & 35.11 \\
\hline Finland & 26 & 30.77 & 30.55 \\
\hline Sweden & 23.35 & 25.77 & \\
\hline
\end{tabular}

Source: based on data from https://ec.europa.eu/eurostat/data/database, Table. Hotels; holiday and other short-stay accommodation; camping grounds, recreational vehicle parks and trailer parks, Foreign country. 


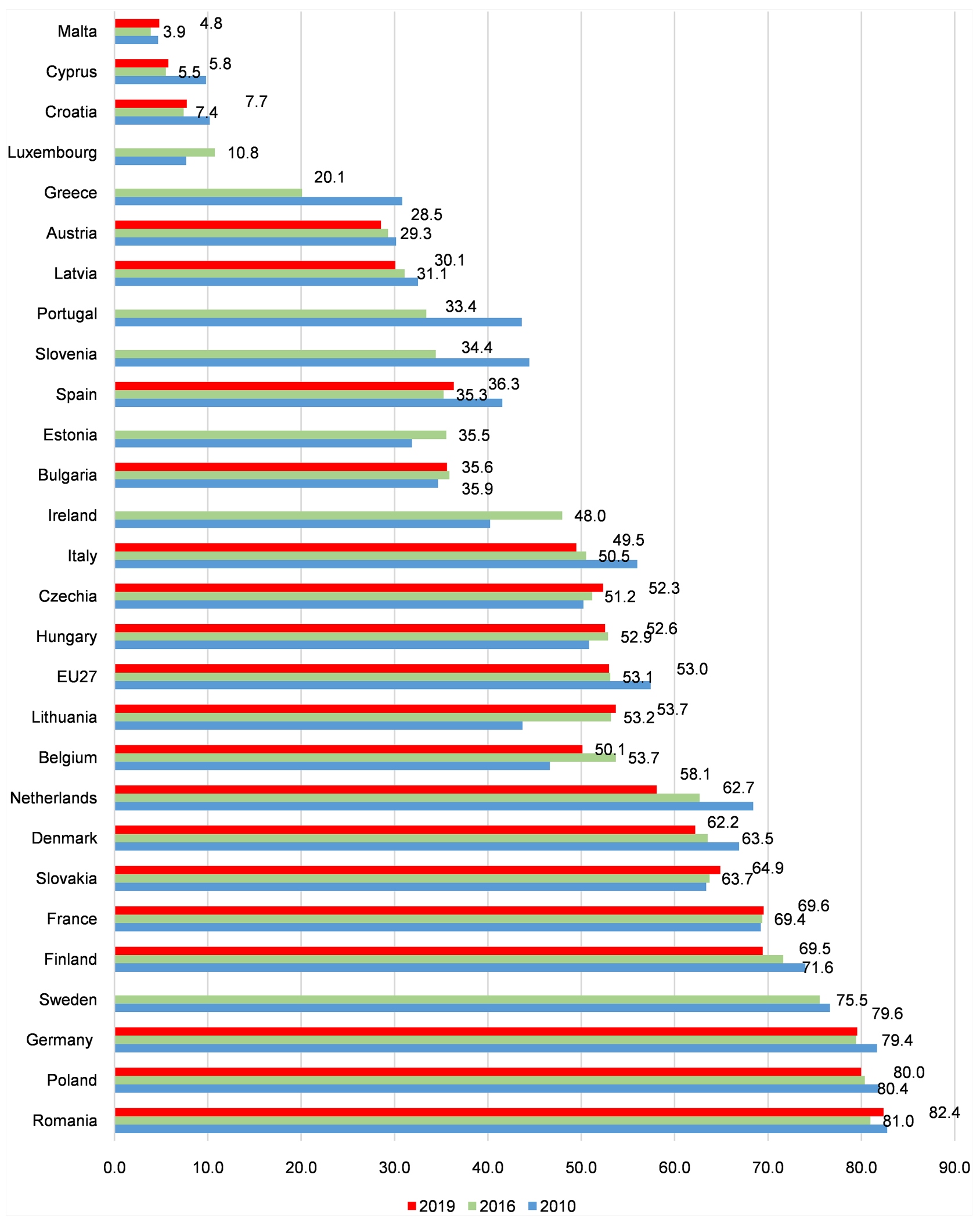

Figure 4. Share of nights spent by domestic tourists of EU27 Member States in total number of tourist nights (\%). Source: based on data from https://ec.europa.eu/eurostat/data/database, Table. Hotels; holiday and other short-stay accommodation; camping grounds, recreational vehicle parks and trailer parks, Reporting country. Note: The data for 2019 for some EU 27 Member States are not available. 
35.00

30.00

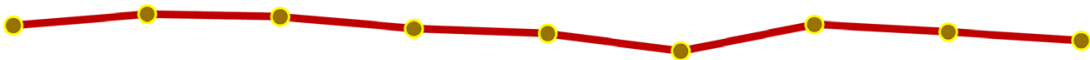

25.00

20.00

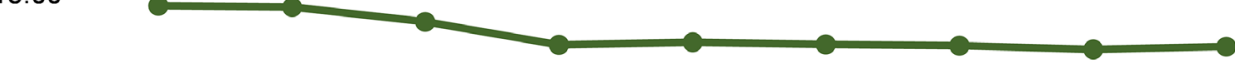

10.00

5.00

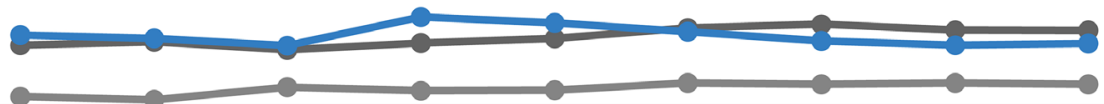

0.00

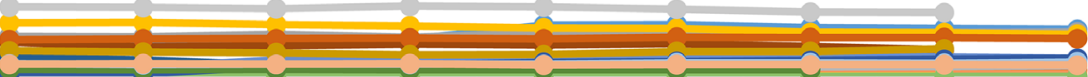

\begin{tabular}{|l|l|l|l|l|l|l|l|r|}
\hline 2010 & 2011 & 2012 & 2014 & 2015 & 2016 & 2017 & 2018 & 2019 \\
\hline
\end{tabular}

- Belgium

\begin{tabular}{|l|l|l|l|}
1.62 & 1.66 & 1.73 & 1.71 \\
\hline
\end{tabular}

- Bulgaria

$0.21 \quad 0.22$

$1.85 \quad 1.83$

—Denmark

\begin{tabular}{l|l}
2.47 & 2.49 \\
\hline
\end{tabular}

$\longrightarrow$ Germany

17.50

17.66

\begin{tabular}{|l|l|}
\hline .22 & 0.26 \\
\hline 1.83 & 1.95 \\
\hline
\end{tabular}

\begin{tabular}{|l|l|}
1.71 & 2.38 \\
\hline
\end{tabular}

2.39

2.25

2.22

2.19

\begin{tabular}{l|l}
0.28 & 0.28 \\
\hline 1.82
\end{tabular}

\begin{tabular}{|l|l|}
0.28 & 0.29 \\
\hline
\end{tabular}

0.29

\begin{tabular}{|l|l|}
0.29 & 0.30 \\
\hline
\end{tabular}

- Estonia

- Ireland

2.40

\begin{tabular}{l|l}
2.34 & 2.23 \\
\hline
\end{tabular}

2.01

1.96

2.03

2.04

$\longrightarrow$ Greece

0.9

\begin{tabular}{l|l}
0.11 & 0.12 \\
\hline
\end{tabular}

17.90

17.54

2.22

2.05

2.02

1.94

$\longrightarrow$ Spain

1.58

\begin{tabular}{|l|l|}
0.76 & 0.53 \\
\hline
\end{tabular}

\begin{tabular}{|l|l|}
0.12 & 0.12 \\
\hline
\end{tabular}

17.74

17.38

18.31

18.85

- - France

7.80

\begin{tabular}{|l|l|}
\hline 1.36 & 1.43 \\
\hline
\end{tabular}

43

\begin{tabular}{|l|l|l|}
\hline 0.55 & 0.30 & 0.29 \\
\hline
\end{tabular}

\begin{tabular}{|l|l|}
\hline 7.95 & 7.58 \\
\hline
\end{tabular}

\section{$\rightarrow$ Croatia}

28.63

29.14

29.03

7.50

\begin{tabular}{|l|l|}
1.47 & 1.52 \\
\hline
\end{tabular}

0.13

0.13

$\longrightarrow$ Italy

0.29

0.30

0.58

28.49

\begin{tabular}{|l|l|}
8.10 & 8.60 \\
\hline
\end{tabular}

1.39

1.22

\begin{tabular}{|l|l|l|}
\hline 8.78 & 8.50 & 8.48 \\
\hline
\end{tabular}

- Cyprus

\begin{tabular}{|l|l|l|l|}
\hline 14.43 & 14.39 & 13.70 & 12.63 \\
\hline
\end{tabular}

27.43

28.69

28.34

27.92

- Latvia

0.00

$0.00 \quad 0.00$

\begin{tabular}{|l|l|l|}
\hline 12.63 & 12.75 & 12.64 \\
\hline
\end{tabular}

0.63

0.71

0.05

0.06

0.09

\begin{tabular}{|l|l|l|}
\hline 0.00 & 0.00 & 0.00 \\
\hline 0.10 & 0.08 & 0.09 \\
\hline
\end{tabular}

12.59

\begin{tabular}{l|l}
12.41 & 12.55 \\
\hline
\end{tabular}

- Luxembourg

$\longrightarrow$ Hungary $\quad 0.46$

$\longrightarrow$ Malta $\quad 0.00$

\section{$\longrightarrow$ Netherlands}

8.26

\begin{tabular}{|l|l|}
\hline 0.07 & 0.39 \\
\hline
\end{tabular}

0.13

0.42

0.00

0.00

0.00

0.07

$0.02 \quad 0.03$

0.43

0.42

0.43

0.11

0.10

0.10

\begin{tabular}{l|l}
0.43 & 0.76
\end{tabular}

0.03

\begin{tabular}{|l|l|l|}
\hline 0.04 & 0.03 & 0.03 \\
\hline
\end{tabular}

0.42

\begin{tabular}{|l|l|}
0.45 & 0.48 \\
\hline
\end{tabular}

$\longrightarrow$ Austria

\section{- Poland}

1.70

0.00

\begin{tabular}{l|l}
0.76 & 0.85 \\
\hline
\end{tabular}

\begin{tabular}{|l|l|}
\hline 0.85 & 0.85 \\
\hline
\end{tabular}

0.03

0.03

8.11

7.78

\begin{tabular}{|l|l|l|}
\hline 0.00 & 0.00 & 0.00 \\
\hline
\end{tabular}

\begin{tabular}{|l|l|l|}
\hline 0.91 & 0.89 & 0.84 \\
\hline
\end{tabular}

- Portugal

5.43

1.74

1.76

\begin{tabular}{|l|l|}
\hline 9.09 & 8.82 \\
\hline
\end{tabular}

8.42

0.00

\begin{tabular}{l|l}
\hline 0.00 & 0.00 \\
\hline
\end{tabular}

- Romania

$\longrightarrow$ Slovenia

—Slovakia

$\longrightarrow$ Finland

Sweden

1.20

\begin{tabular}{l|l|}
$\mathbf{5 . 2 5}$ & $\mathbf{5 . 8 5}$ \\
\hline
\end{tabular}

1.76

\begin{tabular}{|l|l|l|l|l|}
\hline 1.74 & 1.81 & 1.79 & 1.78 & 1.76 \\
\hline 5.71 & 0.04 & 5.98 & 6.04 & 5.97 \\
\hline
\end{tabular}

\begin{tabular}{|l|l|l|l|l|}
\hline 1.74 & 1.81 & 1.79 & 1.78 & 1.76 \\
\hline 5.71 & 0.04 & 5.98 & 6.04 & 5.97 \\
\hline
\end{tabular}

7.98

7.80

7.86

$1.13 \quad 1.09$

\begin{tabular}{l|l}
5.85 & 5.70 \\
\hline
\end{tabular}

\begin{tabular}{|l|l|l|}
\hline 5.70 & 5.71 & 6.04 \\
\hline
\end{tabular}

5.98

\begin{tabular}{|l|l|}
\hline 6.04 & 5.97 \\
\hline
\end{tabular}

\begin{tabular}{l|l}
1.09 & 0.99 \\
\hline
\end{tabular}

\begin{tabular}{|l|l|l|l|l|l|}
\hline 1.20 & 1.13 & 1.09 & 0.99 & 1.02 & 1.14 \\
\hline 0.11 & 0.11 & 0.47 & 0.53 & 0.64 & 0.68 \\
\hline
\end{tabular}

\begin{tabular}{|l|l|l|l|l|l|}
\hline 0.33 & 0.32 & 0.34 & 0.30 & 0.31 & 0.32 \\
\hline 0.59 & 0.55 & 0.57 & 0.56 & 0.57 & 0.62 \\
\hline 0.57 & 0.58 & 0.57 & 0.58 & 0.53 & 0.54 \\
\hline 3.21 & 3.19 & 3.13 & 3.26 & 3.21 & 3.12 \\
\hline
\end{tabular}

\begin{tabular}{l|l|}
1.15 \\
0.75 \\
0.32
\end{tabular}

1.27

\begin{tabular}{|l|l|l|}
\hline 0.75 & 0.80 & 0.85 \\
\hline 0.32 & & \\
\hline 0.62 & 0.61 & 0.65 \\
\hline
\end{tabular}

\begin{tabular}{|l|l|l|}
\hline 0.75 & 0.80 & 0.85 \\
\hline 0.32 & & \\
\hline 0.62 & 0.61 & 0.65 \\
\hline
\end{tabular}

\begin{tabular}{l|l|l|}
\hline 0.62 & 0.61 & 0.65 \\
\hline 0.55 & 0.55 & 0.53 \\
\hline
\end{tabular}

\begin{tabular}{|l|l|}
\hline 2.59 & 0.55 \\
\hline 2.99 & 2.97 \\
\hline
\end{tabular}

Figure 5. Share of the number of nights spent by domestic tourists of Member States in the total EU27 (\%). Source: based on data

from https://ec.europa.eu/eurostat/data/database, Table. Hotels; holiday and other short-stay accommodation; camping grounds, recreational vehicle parks and trailer parks, Reporting country. 
Table 2. Nights spent at tourist accommodation establishment, monthly data for 2019 (million).

\begin{tabular}{|c|c|c|c|c|c|c|c|c|c|c|c|c|c|}
\hline & M01 & M02 & M03 & M04 & M05 & M06 & M07 & M08 & M09 & M10 & M11 & M12 & $\begin{array}{l}\text { Share of number of } \\
\text { nights spent in the } \\
\text { period M04-M09 in } \\
2019 \text { in total (\%) }\end{array}$ \\
\hline EU27 & 128.2 & 138.1 & 160.4 & 201.8 & 228.8 & 314.8 & 440.1 & 477.3 & 283.2 & 206.1 & 135.2 & 139.9 & $68.2 \%$ \\
\hline Belgium & 1.8 & 2.2 & 2.8 & 4.0 & 3.6 & 3.9 & 5.9 & 5.7 & 3.6 & 3.6 & 2.7 & 2.8 & $62.5 \%$ \\
\hline Bulgaria & 0.9 & 0.9 & 0.9 & 1.0 & 1.4 & 4.0 & 6.0 & 6.4 & 3.1 & & & 0.9 & $86.0 \%$ \\
\hline Czechia & 3.3 & 3.7 & 3.8 & 4.1 & 4.7 & 5.2 & 8.1 & 8.0 & 4.9 & 4.4 & 3.4 & 3.5 & $61.4 \%$ \\
\hline Denmark & 1.3 & 1.4 & 1.6 & 2.7 & 3.2 & 3.8 & 7.1 & 4.8 & 2.7 & 2.4 & 1.7 & 1.4 & $71.4 \%$ \\
\hline Germany & 21.8 & 23.4 & 27.9 & 35.3 & 39.3 & 45.7 & 53.5 & 52.8 & 42.7 & 40.4 & 27.4 & 26.8 & $61.6 \%$ \\
\hline Estonia & 0.4 & 0.4 & 0.4 & 0.5 & 0.6 & 0.7 & 1.0 & 0.9 & 0.5 & 0.5 & 0.5 & 0.5 & $60.9 \%$ \\
\hline Greece & 1.1 & 1.3 & 1.9 & 3.6 & 11.6 & 18.9 & 24.4 & 26.4 & 18.2 & 8.6 & 1.8 & 1.7 & $86.3 \%$ \\
\hline Spain & 21.0 & 22.2 & 28.3 & 35.7 & 41.0 & 50.0 & 63.0 & 72.4 & 50.0 & 38.7 & 24.2 & 23.3 & $66.5 \%$ \\
\hline France & 19.3 & 21.3 & 24.1 & 34.5 & 33.2 & 45.5 & 76.2 & 89.6 & 39.5 & 24.5 & 18.4 & 20.3 & $71.3 \%$ \\
\hline Croatia & 0.5 & 0.5 & 0.9 & 3.0 & 4.9 & 13.0 & 25.5 & 27.7 & 10.4 & 3.1 & 0.8 & 0.8 & $92.7 \%$ \\
\hline Italy & 17.5 & 18.1 & 21.4 & 28.5 & 31.1 & 54.4 & 74.7 & 84.6 & 46.4 & 27.2 & 15.3 & 17.7 & $73.2 \%$ \\
\hline Cyprus & 0.3 & 0.4 & 0.7 & 1.1 & 1.9 & 2.3 & 2.5 & 2.6 & 2.3 & 2.1 & 0.8 & 0.4 & $73.1 \%$ \\
\hline Latvia & 0.3 & 0.3 & 0.3 & 0.4 & 0.5 & 0.6 & 0.8 & 0.7 & 0.5 & 0.4 & 0.4 & 0.4 & $62.8 \%$ \\
\hline Lithuania & 0.5 & 0.4 & 0.5 & 0.6 & 0.8 & 1.0 & 1.3 & 1.3 & 0.8 & 0.6 & 0.6 & 0.6 & $64.1 \%$ \\
\hline Luxembourg & 0.1 & 0.1 & 0.2 & 0.2 & 0.3 & 0.4 & 0.4 & 0.4 & 0.2 & 0.2 & 0.2 & 0.1 & $67.9 \%$ \\
\hline Hungary & 1.6 & 1.6 & 2.0 & 2.4 & 2.7 & 3.4 & 4.9 & 5.1 & 2.7 & 2.6 & 2.1 & 2.1 & $63.9 \%$ \\
\hline Malta & 0.5 & 0.5 & 0.7 & 0.9 & 0.9 & 1.0 & 1.1 & 1.2 & 1.0 & 1.0 & 0.7 & 0.6 & $60.6 \%$ \\
\hline Netherlands & 5.5 & 5.5 & 7.2 & 11.2 & 10.5 & 13.8 & 15.6 & 19.0 & 11.3 & 10.4 & 7.0 & 6.5 & $65.9 \%$ \\
\hline Austria & 12.2 & 13.8 & 12.2 & 7.2 & 6.7 & 11.0 & 15.6 & 16.7 & 10.0 & 7.6 & 4.9 & 10.1 & $52.5 \%$ \\
\hline Poland & 5.4 & 5.7 & 5.7 & 6.0 & 7.9 & 9.3 & 13.2 & 13.4 & 8.3 & 6.9 & 6.0 & 5.5 & $62.3 \%$ \\
\hline Portugal & 3.3 & 3.6 & 4.9 & 6.4 & 7.0 & 7.8 & 9.5 & 11.8 & 8.4 & 6.7 & 4.3 & 3.8 & $65.6 \%$ \\
\hline Romania & 1.5 & 1.5 & 1.5 & 1.8 & 2.2 & 3.0 & 4.4 & 5.1 & 3.0 & 2.4 & 1.9 & 1.7 & $65.0 \%$ \\
\hline Slovenia & 0.8 & 0.9 & 0.8 & 1.1 & 1.1 & 1.7 & 2.5 & 2.9 & 1.5 & 1.1 & 0.7 & 0.8 & $68.3 \%$ \\
\hline Slovakia & 1.0 & 1.2 & 1.1 & 1.1 & 1.4 & 1.5 & 2.3 & 2.4 & 1.5 & 1.4 & 1.2 & 1.0 & $59.4 \%$ \\
\hline Finland & 1.5 & 1.7 & 1.9 & 1.6 & 1.6 & 2.3 & 3.3 & 2.4 & 1.8 & 1.7 & 1.6 & 1.8 & $56.0 \%$ \\
\hline Sweden & 3.2 & 3.5 & 3.9 & 3.9 & 5.2 & 6.8 & 13.0 & 8.5 & 4.4 & 4.0 & 3.6 & 3.1 & $66.3 \%$ \\
\hline
\end{tabular}

Source: based on data from https://ec.europa.eu/eurostat/data/database, Table. Nights spent at tourist accommodation establishments-monthly data [tour_occ_nim, download, 03.05.2020. Note: There are no data available for Ireland. 
In the same period, the highest and the most stable net occupancy rate of bed-places and bedrooms in hotels and similar accommodation was recorded in Austria, Luxembourg, Belgium, Czechia, Romania, Germany, Slovakia, etc. The most unstable rate was recorded in Croatia, Greece, Cyprus, Malta, Portugal, etc. (Figure 6).

\section{Direct and Indirect Effect of Tourism Sector to Economy, Challenges of COVID-19 Crisis}

Tourism represents a list of activities like transport, travelling, accommodation, food and beverage service, cultural entertainment, sports events, trade of local products, trade fairs. All these activities come together on supply-side of tourism product starting with travel and hotel accommodation followed by with suppliers of resources like food and beverage, culture, sports, fun, etc. In the recent years, globalization has pushed the development of service sector as well as boosted the tourism rapidly.

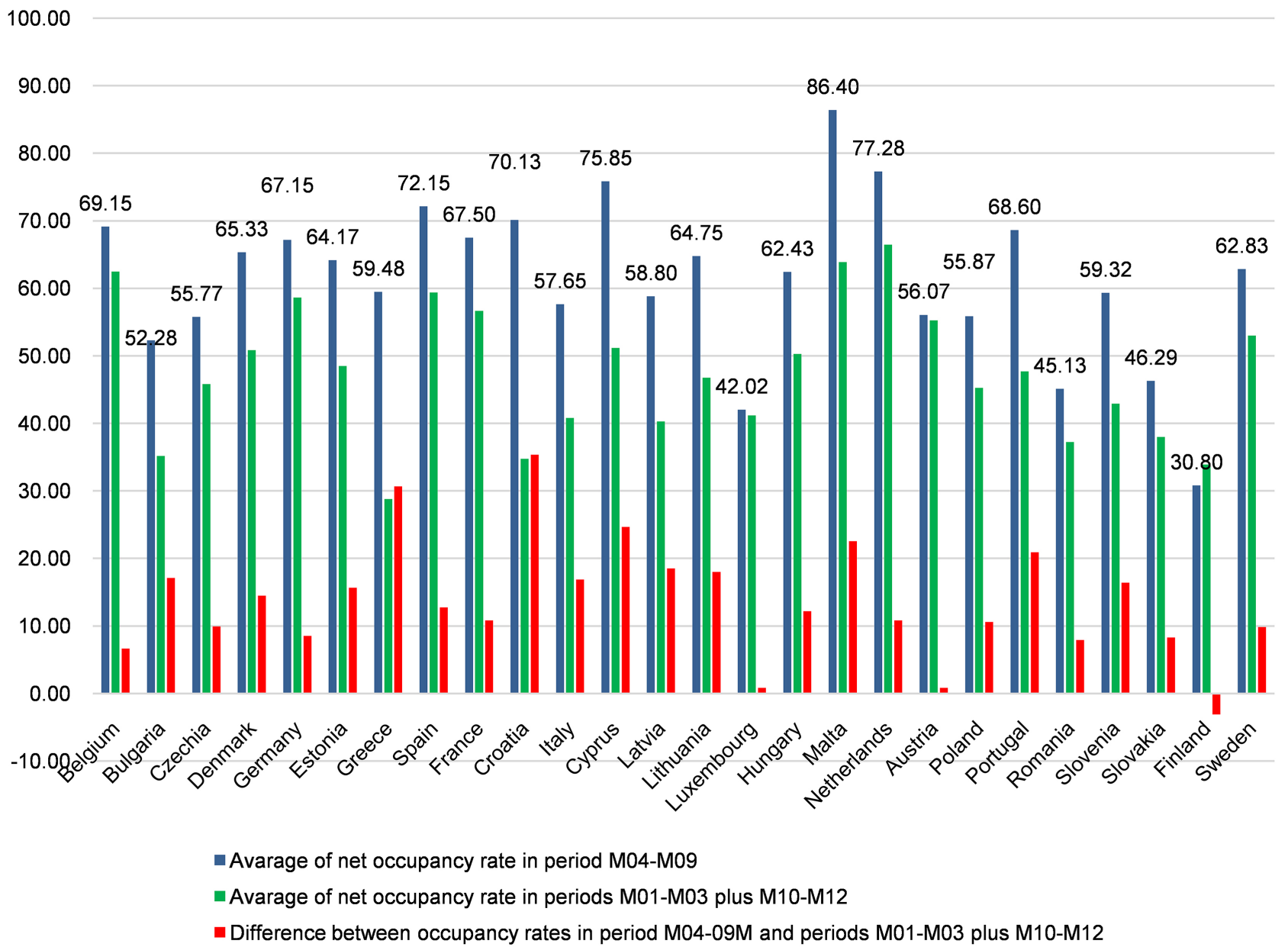

Figure 6. Net occupancy rate of bed-places and bedrooms in hotels and similar accommodation in the EU countries, in different periods (seasons) of 2019. Source: based on data from https://ec.europa.eu/eurostat/data/database, Table. Net occupancy rate of bed-places and bedrooms in hotels and similar accommodation (NACE Rev. 2, I, 55.1)—monthly data [tour_occ_mnor], download, 03.05.2020. Note: There are no data available for Ireland. 
The tourism has a direct and indirect impact on the national and global economy. Its direct impact is through GDP as well as on the employment. Indirect effects are shown through multiplicative effect on other economic sectors connected to tourism and accommodation like travel, but also on agriculture production, industrial production and trade. Indirect effects of tourism can be seen in the investment activity and tax collection. Increasing and decreasing demand for travel products has many companies to invest during the last decade. Tourism sector has expanded the number of enterprises, especially small companies improving the accommodation segment. In the recent years, many hotels have surfaced with refurbishment their capacities to the 5 stars and luxury hotels. Improvement of supply side parallel with increasing demand resulted in higher prices.

In the period of 2012-2017, the number of enterprises in the EU Member countries was increasing $7 \%$ in total economy, in total service sector $15 \%$, while in tourism this growth has been 23\%. In 2017, in the Member States, there were 1.9 million enterprises in accommodation and food industry hiring around 10.2 million people, according to Eurostat (www.eurostat.ec). The deep analysis shows us that around 1.7 million enterprises were small, with $0-9$ employed while only around 17,000 were big with more than 50 employees. During the recession caused by COVID 19, we expect stronger exit of small companies and surviving of the big ones. If the tourism realizes the pessimistic scenario and the drop to $10 \%$ of the average arrivals and spent overnights, the number of employees will drop for nearly $50 \%$ on 5.7 million. In the case of a better scenario and new additional $10 \%$ of tourists and nights, we forecast needs for additional 0.5 million of new employees.

Tourism with its revenues contributes to the exports receipts directly, but it also creates new jobs in its segment and in related industries. Therefore, the two direct effects are focused on increasing the export revenue and employment. Furthermore, tourism opens export market but locally, for many domestic products like food, drinks, some industry products, real estates, etc., and it contributes to the commodity exports. Tourism generates investments and sets strong relations with construction sector, furniture manufacturer and equipment, presenting its indirect effects. All those activities in connection with tourism fill up the state budget through value added tax, profit tax and income tax-which are indirect effects.

To achieve above-mentioned direct and indirect effects, the GDP in both countries, origin and destination, should have a positive growth rate. Greater economic volume makes tourism more interesting because people have greater buying power to allocate the leisure activities or because the greater wealth of the host country allows it to offer, higher-quality services (Marti \& Puertas, 2017).

In 2018, tourism in EU-27 represented only 1.2 percent of GDP looking through travel receipts in balance of payment. However, this share was very high for some small and less developed countries like Croatia (18.4\%), Cyprus (13.9\%), 
Malta (12.7\%) and Greece (8.7\%). GDP of the four big countries, which are realizing more than $50 \%$ of the European tourism, was not depending on travelling and tourism because it represents only $1.1 \%$ in Germany, $2.4 \%$ in Italy and France and 5.7\% in Spain (Eurostat, 2020a, 2020b).

Tourism has a great importance in the economy of some EU countries. This is especially true for Croatia, which has a $10.9 \%$ share in gross value added ${ }^{1}$, significantly more than other EU27 Member States, for example Portugal 6.7\%, Spain $6.6 \%$, Italy $6 \%$, Hungary $5.8 \%$, etc. (Table 3 ). This demonstrates high sensitivity of economic development and growth to tourism, which is a challenge for economic policy makers and entrepreneurs to stimulate the development more intensively and invest in other promising activities.

Table 3. Share of direct gross value added in the gross value added in the EU Member States economy, various years.

\begin{tabular}{|c|c|c|c|c|}
\hline & Year & $\begin{array}{c}\text { Gross value } \\
\text { added of tourism } \\
\text { (mill EUR, basic } \\
\text { prices) }\end{array}$ & $\begin{array}{l}\text { Gross value added } \\
\text { of the total economy } \\
\text { (mill EUR, basic } \\
\text { prices) }\end{array}$ & $\begin{array}{l}\text { Contribution } \\
\text { of tourism to } \\
\text { gross value } \\
\text { added, in \% }\end{array}$ \\
\hline Croatia & 2016 & 4.215 & 38.696 & 10.9 \\
\hline Portugal & 2015 & 10.468 & 156,839 & 6.7 \\
\hline Spain & 2011 & 64.756 & 983,670 & 6.6 \\
\hline Italy & 2015 & 87.823 & 1.463 .717 & 6.0 \\
\hline Hungary & 2012 & 4.823 & 83.634 & 5.8 \\
\hline Latvian & 2013 & 837 & 20.110 & 4.2 \\
\hline Estonia & 2011 & 566 & 14.616 & 3.9 \\
\hline Slovenia & 2014 & 1.182 & 32.503 & 3.6 \\
\hline Netherlands & 2014 & 20.336 & 604,814 & 3.4 \\
\hline Denmark & 2013 & 7.424 & 223,851 & 3.3 \\
\hline Austria & 2014 & 18.721 & 604,814 & 3.1 \\
\hline Lithuania & 2013 & 867 & 31.690 & 2.7 \\
\hline Czech Republic & 2014 & 3.733 & 141,582 & 2.6 \\
\hline Slovakia & 2013 & 1.739 & 67.522 & 2.6 \\
\hline Finland & 2012 & 4.312 & 172,417 & 2.5 \\
\hline Romania & 2013 & 2.627 & 126,843 & 2.1 \\
\hline Poland & 2012 & 6.862 & 344,985 & 2.0 \\
\hline
\end{tabular}

Source: Tourism Satellite Account, Institute for Tourism, The Croatian Bureau of Statistics, The Ministry of Tourism of the Republic of Croatia, Zagreb, 15 January 2019.

${ }^{1}$ Sum of Gross Value Added (in basic prices) generated by all activities as a result of domestic consumption by tourists and the Net Tax on products included into tourism expenditures in buying prices is equal to the direct Gross Domestic Product of tourism. 
According to the current situation with Coronavirus, some borders locked, restrictions and unknown future in the short run, we can expect the biggest loss in countries with high seasonality and tourism share in GDP. Many countries have opened their borders at the end of May or later, but strong recommendations of the Governments to inhabitants is to spend their holidays in their own countries will reorient the common tourism route. Along with the GDP drop, decreasing income and increasing unemployment, many families will not go on holidays and others will stay in their own countries. We can forecast three possible scenarios:

- the drop in outbound tourism nights for $90 \%$ with increase inbound for $20 \%$

- the drop in outbound tourism nights for $80 \%$ with increase inbound for $40 \%$

- the drop in outbound tourism nights for $90 \%$ with increase inbound for $50 \%$

The fear of a new wave of COVID-19 and continuous danger from China and some other world's centres of Corona virus will not allow tourism growth more than $30 \%$ of 2019. In these circumstances, we forecast high job losses and numerous bankruptcies, especially in the small tourism companies, but also in the entire economy. Many families will be left without income, so this will also be the reason for not travelling. Due to the multiplier effect of tourism on related activities, it is difficult to estimate the total effects on the entire European economy, but we will do this for Croatia below.

\section{Quantitative Analysis of the Correlation between Tourism Trends and Economy in Croatia}

In order to additionally analyze the correlation between tourism and economy and to assess the impact of the Covid-19, we have calculated the impact of rising number of nights spent by tourists on GDP growth and tax revenue using regression analysis.

\subsection{Correlation between Economic Growth and Number of Nights Spent by Tourists}

The regression analysis model was used to examine the correlation between economic growth, i.e. the growth rate of gross domestic product (GDP) and the number of nights spent by tourists.

The basics of the model are:

- Linear form of the equation: $y=a+b x$

where:

- Parameter a-coefficient that shows value of the dependent variable in case when the independent variable is zero.

- Parameter $\mathrm{b}$-regression coefficient, showing how much the dependent variable changes on average if the independent variable varies by one.

- $x$-number of nights spent by tourists (in millions).

- $y$-GDP growth rate (\%).

- Data for the period 2010-2019.

- $\mathrm{r}$-coefficient of correlation-correlation between independent variable and 
dependent variable.

- $\mathrm{r}^{2}$-coefficient of determination-correlation between independent variable and dependent variable.

- F-statistical significance.

The main data used in the model is shown in Table 4.

By using Data Analysis section of the Excel, the following results were obtained.

\begin{tabular}{|c|c|c|c|c|c|c|c|c|}
\hline \multicolumn{2}{|c|}{ Regression Statistics } & & & & & & & \\
\hline Multiple R & 0.790895918 & & & & & & & \\
\hline R Square & 0.625516353 & & & & & & & \\
\hline Adjusted R Square & 0.578705898 & & & & & & & \\
\hline Standard Error & 1.381301625 & & & & & & & \\
\hline Observations & 10 & & & & & & & \\
\hline \multicolumn{9}{|l|}{ ANOVA } \\
\hline & $d f$ & SS & MS & $F$ & Significance $F$ & & & \\
\hline Regression & 1 & 25.49604656 & 25.49605 & 13.36275 & 0.006442867 & & & \\
\hline Residual & 8 & 15.26395344 & 1.907994 & & & & & \\
\hline Total & 9 & 40.76 & & & & & & \\
\hline & Coefficients & Standard Error & t Stat & P-value & Lower 95\% & Upper 95\% & Lower $95.0 \%$ & Upper $95.0 \%$ \\
\hline Intercept & -5.04655309 & 1.710796211 & -2.94983 & 0.018431 & -8.991656231 & -1.10144996 & -8.9916562 & -1.10144996 \\
\hline x: Broj ukupnih noćenja & 0.088272024 & 0.024147667 & 3.655509 & 0.006443 & 0.032587403 & 0.14395664 & 0.0325874 & 0.14395664 \\
\hline
\end{tabular}

$$
\mathrm{Y}=-5.047+0.088 \mathrm{x}
$$

Since the empirical analysis of significance level $\mathrm{F}=0.0064$ is less than the theoretical 0.05 , it is concluded that the regression model is statistically significant.

Table 4. GDP growth rate in Croatia and total number of nights spent by tourists between 2010 and 2019.

\begin{tabular}{ccc}
\hline Years & y: GDP growth rate & $\begin{array}{c}\text { x: number of total tourism } \\
\text { nights (mill.) }\end{array}$ \\
2010 & -1.5 & 37.009 \\
2011 & -0.3 & 39.251 \\
2012 & -2.2 & 62.184 \\
2013 & -0.5 & 64.418 \\
2014 & -0.1 & 66.125 \\
2015 & 2.4 & 71.339 \\
2016 & 3.5 & 77.824 \\
2017 & 3.1 & 86.095 \\
2018 & 2.7 & 89.568 \\
2019 & 2.9 & 91.178 \\
\hline
\end{tabular}

Sources: based on data from: https://ec.europa.eu/eurostat/data/database Table. Hotels; holiday and other short-stay accommodation; camping grounds, recreational vehicle parks and trailer parks, Total and Table Real GDP growth rate-volume [TEC00115]. 
Croatia's GDP growth rate is related to the number of nights spent by tourists. The correlation coefficient $r$ is 0.791 , the determination coefficient $r^{2}$ is 0.626 , which is less than 1 and indicates a medium correlation. If the number of nights spent by tourists increases by 1 million, the GDP growth rate increases by $0.0882 \%$ (parameter b). If the number of nights spent by tourists is 0 , the rate of GDP growth/reduction would be-5.047 (parameter a). If the number of nights was 30 million (a third of what was achieved in 2019), the rate of decline in GDP would be $-2.4 \%$, meaning that nights spent by tourists would affect the drop in GDP by that much. When explaining the coefficients and figures, it should be taken into account that other factors also influence GDP growth, which explains the forecast of GDP decline by about $10 \%$ in 2020 .

\subsection{Correlation between Tax Revenue and the Number of Nights Spent by Tourists}

A regression analysis model was also used to study the relationship between tax revenues and the number of nights spent by tourists:

- $\mathrm{x}$-number of nights spent by tourists (in millions)

- $y$-tax revenue (in millions)

- Data for the period 2010-2019

The main data used in the model is shown in Table 5.

By using Data Analyses from the Excel, following results were obtained.

\begin{tabular}{|c|c|c|c|c|c|c|c|c|}
\hline \multicolumn{9}{|c|}{ SUMMARY OUTPUT } \\
\hline \multicolumn{9}{|c|}{ Regression Statistics } \\
\hline Multiple R & 0.87287494 & & & & & & & \\
\hline R Square & 0.76191067 & & & & & & & \\
\hline Adjusted R Squar & 0.7321495 & & & & & & & \\
\hline Standard Error & 3933.16137 & & & & & & & \\
\hline Observations & 10 & & & & & & & \\
\hline \multicolumn{9}{|l|}{ ANOVA } \\
\hline & $d f$ & SS & $M S$ & $F$ & Significance $F$ & & & \\
\hline Regression & 1 & 396038708.9 & $3.96 \mathrm{E}+08$ & 25.60083 & 0.00097738 & & & \\
\hline Residual & 8 & 123758066.8 & 15469758 & & & & & \\
\hline \multirow[t]{2}{*}{ Total } & 9 & 519796775.7 & & & & & & \\
\hline & Coefficients & Standard Error & t Stat & $P$-value & Lower 95\% & Upper 95\% & Lower $95.0 \%$ & Upper $95.0 \%$ \\
\hline Intercept & 45432.6822 & 4871.374538 & 9.326461 & $1.43 \mathrm{E}-05$ & 34199.2724 & 56666.09206 & 34199.2724 & 56666.09206 \\
\hline $\begin{array}{l}\text { x: Broj ukupnih } \\
\text { noćenja (u mil.) }\end{array}$ & 347.900842 & 68.75882181 & 5.059727 & 0.000977 & 189.3427143 & 506.4589692 & 189.3427143 & 506.4589692 \\
\hline
\end{tabular}

$$
\mathrm{Y}=45,432.7+347.9 \mathrm{x}
$$

Since the empirical analysis of the significance level $\mathrm{F}=0.00098$ is lower than the theoretical 0.05 , it is concluded that the regression model is statistically significant. 
Table 5. Croatia's tax revenues and the total number of nights spent by tourists in the period 2010-2019.

\begin{tabular}{ccc}
\hline Years & $\begin{array}{c}\text { y: budget tax revenue } \\
\text { (in mill. kn) }\end{array}$ & $\begin{array}{c}\text { x: total number of tourism } \\
\text { nights (in mill.) }\end{array}$ \\
\hline 2010 & $62.856,582$ & 37.009 \\
2011 & $61.422,186$ & 39.251 \\
2012 & $64.693,898$ & 62.184 \\
2013 & $63.044,946$ & 64.418 \\
2014 & $63.349,864$ & 66.125 \\
2015 & $68.280,769$ & 71.339 \\
2016 & $71.958,532$ & 77.824 \\
2017 & $75.504,280$ & 86.095 \\
2018 & $78.404,735$ & 89.568 \\
2019 & $83.119,933$ & 91.178 \\
\hline
\end{tabular}

Sources: based on data from: https://ec.europa.eu/eurostat/data/database Table. Hotels; vacations and other short stays; vacationers, recreational parks and trailer parks, Total

https://mfin.gov.hr/pristup-informacijama/statistika-i-izvjesca/vremenske-serije-podataka/98, Tables of the data "State budget".

Tax revenues to the budget of Croatia are related to the number of nights spent by tourists. The correlation coefficient $r$ is 0.8729 and the determination coefficient $\mathrm{r}^{2}$ is 0.762 , which is less than 1 and shows a strong correlation. If the number of nights increases by 1 million, tax revenue would increase by HRK 347.9 million (parameter $b$ ). If the number of nights spent by tourists is 0 , tax revenue is HRK 45.432 billion (parameter a) compared to approximately 83 billion in 2019. If the number of nights is 30 million (one third of the 2019), the tax revenue would be HRK 55.9 billion. When explaining the coefficients and amounts, it should be taken into account that other factors also affect tax revenues.

\section{Conclusion}

From the mid-twentieth century, the share of service sector of GDP has been expanded and by emphasizing the importance of services and among them, tourism has taken a very high position and importance in the economy. The direct contribution of the travelling and tourism industry accounted for 3.3 percent of the total global GDP in 2019. In 2019 all destinations worldwide registered around 1.5 billion international tourist arrivals and from that number, 50.8\% arrivals were reported in Europe, 25\% in Asia and Pacific, 15\% in America and $5 \%$ Africa.

Some countries depend strongly on tourism revenues like Maldives (38.9\%), British Virgin Islands (32.96\%), Aruba, etc. Many countries took the lock-down strategy at the beginning of the Corona crisis in 2020 with a strong impact on GDP and government's revenues, while it has the most powerful effect for the tourism-dependent states. From the beginning of June, according to forecasting, 
all business activity are running again but tourism and travelling will face with deep decline due to the fact that many countries will not open their borders or have some restrictions.

Tourist activity in the EU27 has increased by $31.4 \%$ between 2010 and 2019, with, in total, 2.844 billion number of nights spent by tourists in 2019, of which the number of nights spent by foreign tourists is $47.7 \%$. Tourism in EU27 is highly concentrated to four countries. More than $62.95 \%$ of all nights spent at tourist accommodation establishments in $E U$ were realized in Spain (16.52\%), than in France (15.79\%), in Germany (15.37\%), in Italy $15.36 \%$, etc.

The tourism potential of the Republic of Croatia, according to the total number of nights spent by tourists, was $3.28 \%$ of the total number of nights spent by tourists in the EU27 (2019), with a trend of growth. The number of nights spent by tourists in Croatia in 2019 was 91.178 million, compared to 2.844 billion in EU27.

However, Croatia has significantly more potential in relation to the share of the number of nights spent by foreign tourists in the EU27, which is $6.29 \%$ in 2019 (7th in a row), compared to $3.61 \%$ in 2010 with a significant growth trend from 2010 to 2017, and after that, only a slight growth. The number of nights spent by tourists in Croatia in 2019 was 84.124 million, compared to 1.337 billion in EU27.

The tourism has a direct and indirect impact on the national and global econo$m y$. Its direct impact is through GDP as well as on the employment. Indirect effects are shown through multiplicative effect on other economic sectors connected to tourism and accommodation like travel, but also on agriculture production, industrial production and trade. Indirect effects of tourism can be seen in the investment activity and tax collection.

Tourism has great importance in the economy of some EU countries. This is especially true for Croatia, which has $10.9 \%$ share in gross value added, significantly higher than other EU27 Member States, for example Portugal 6.7\%, Spain $6.6 \%$, Italy $6 \%$, Hungary $5.8 \%$, etc. This demonstrates high sensitivity of economic development and growth to tourism, which is a challenge for economic policy makers and entrepreneurs to stimulate the development more intensively and invest in other promising activities.

For the purpose of further analysis of the correlation between tourism and the economy, calculation was performed by using regression analysis, in order to determine the impact of the growth of nights spent by tourists on the GDP growth and tax revenues.

If the number of nights spent by tourists is to be 30 million (one third of those achieved in 2019), the rate of decline in GDP would be $-2.4 \%$, i.e. a decrease in the number of nights spent by tourists would affect the growth/decline rate of GDP, while the rest of the expected decline of about $10 \%$ would be caused by other factors, such as drop in the economic activities, export, investment, etc.

If the number of nights spent by tourists is to be 30 million, tax revenue would 
amount to HRK 55.9 billion, which is about 10.4 billion more than if the number of nights spent by tourists was 0 .

\section{Conflicts of Interest}

The author declares no conflicts of interest regarding the publication of this paper.

\section{References}

Eurostat (2020a). https://ec.europa.eu/eurostat/data/database

Eurostat (2020b). Tourism Statistic/Statistics Explained.

https://ec.europa.eu/eurostat/statistics-explained/pdfscache/1171.pdf

Ilo.org (2011). Employment in the Tourism Industry to Grow Significantly. https://www.ilo.org/global/publications/world-of-work-magazine/articles/WCMS 157 893/lang--en/index.htm

Lee, C. G. (2008). Tourism and Economic Growth: The Case of Singapore. Regional and Sectoral Economic Studies, 8, 89-98.

Marti, L., \& Puertas, R. (2017). Determinants of Tourist Arrivals in European Mediterranean Countries: Analysis of Competitiveness. European Journal of Tourism Research, 15, 131-142.

https://riunet.upv.es/bitstream/handle/10251/109185/EJTR\%2015-131.pdf?sequence=1 \&isAllowed $=\mathrm{y}$

OECD (2020). Tourism Trends and Policies 2020.

Pololikashvili, Z. (2018). EU Tourism Trends, UNWTO. https://www.e-unwto.org/doi/pdf/10.18111/9789284419470

Statista.com (2020).

https://www.statista.com/statistics/1099933/travel-and-tourism-share-of-gdp

Tourism Satellite Account, The Croatian Bureau of Statistics, The Ministry of Tourism of the Republic of Croatia (2019). Tourism Satellite Account, Zagreb, January 15th 2019.

World Bank (2020). Table. Travel and Tourism Direct Contribution to GDP. https://tcdata360.worldbank.org/indicators

World Tourism Barometer, January 2020, UNWTO. 